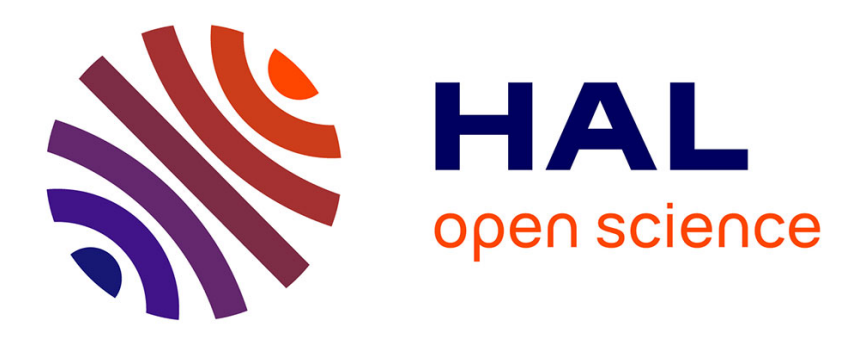

\title{
Middle-term thorium strategy for PWR fleets
}

Guillaume Martin, R. Girieud

\section{- To cite this version:}

Guillaume Martin, R. Girieud. Middle-term thorium strategy for PWR fleets. Energy Policy, 2016, 99, pp.147 - 153. 10.1016/j.enpol.2016.09.062 . cea-01908264

\section{HAL Id: cea-01908264 https://hal-cea.archives-ouvertes.fr/cea-01908264}

Submitted on 30 Oct 2018

HAL is a multi-disciplinary open access archive for the deposit and dissemination of scientific research documents, whether they are published or not. The documents may come from teaching and research institutions in France or abroad, or from public or private research centers.
L'archive ouverte pluridisciplinaire HAL, est destinée au dépôt et à la diffusion de documents scientifiques de niveau recherche, publiés ou non, émanant des établissements d'enseignement et de recherche français ou étrangers, des laboratoires publics ou privés. 


\title{
Middle-term thorium strategy for PWR fleets
}

\author{
G. Martin*, R. Girieud \\ CEA - DEN/DER/SPRC/LECy, Bât. 230, 13108 Saint-Paul-Lez-Durance Cedex, France
}

\section{A R T I C L E I N F O}

\section{Keywords:}

Nuclear energy

Thorium

LWR

\begin{abstract}
A B S T R A C T
Thorium constitutes a natural resource alternative to uranium to fuel nuclear fission power plants. This study explores an original way to benefit from thorium with pressurized water reactors (PWR). It relies on a versatile reactor $\mathrm{EPR}^{\mathrm{TM}}$ core concept which well circumscribes thorium fuel reprocessing and re-fabrication

Fleets representative of what can be deployed at the scale of a small country were simulated using the scenario software COSI6. The cornerstone of this study is here the possibility to multi-recycle plutonium into $\mathrm{Pu} / \mathrm{Th}$ fuel as plutonium degradation is softened by mixing it with high-grade fissile matters. Plutonium content inside $\mathrm{Pu} / \mathrm{Th}$ fuel remains then far below the limit existing in PWR for safety reasons. This synergistic effect between $\mathrm{U} / \mathrm{Pu}$ and $\mathrm{U} / \mathrm{Th}$ cycles enables a better valorization of fissile elements present in spent fuels.

Improved plutonium management makes possible to stabilize spent fuel stocks and the plutonium inventory at the cycle back-end. Thanks to multi-recycling allowed by the $\mathrm{U} / \mathrm{Pu} / \mathrm{Th}$ studied scheme, uranium resource savings exceed 25\%. Minor actinides production is also reduced even though production of curium alone increases. These results reveal that thorium introduction in standard PWR may be a sustainable middle-term option, assuming that $\mathrm{U} / \mathrm{Pu} / \mathrm{Th}$ fuel reprocessing and re-fabrication would become available.
\end{abstract}

\section{Introduction}

There are basically three ways to use thorium in civil electronuclear systems. In near future (typically before 2030), it might be introduced in small quantities (5-10\%) in existing nuclear reactors as an oxide fuel additive to improve core power flattening and neutronics. It may also allow to reduce burnable poisons such as gadolinium (NEA, 2014), since ${ }^{232} \mathrm{Th}$ captures around twice more than ${ }^{238} \mathrm{U}$. Long-term thorium deployment strategies (after 2050) consist in building up a reactor fleet ultimately relying on a closed fuel cycle: new reactor concepts (Heuer et al., 2014; Schaffer, 2013) are then to develop to optimize the thorium conversion and the use of ${ }^{233} \mathrm{U}$ as a fissile element, as in the three-stage development program currently supported by India (Rodriguez and Bhoje, 1998). In particular, high-temperature gascooled reactors (HTGR) are being studied as they constitute interesting innovative GEN-IV concepts (Cerullo and Lomonaco, 2012) for advanced $\mathrm{Pu} / \mathrm{Th}$ cycles (Mazzini et al., 2008), which may target waste reduction (Cerullo et al., 2015; Bomboni et al., 2008). Thorium resources are indeed abundant enough for a long-term and sustainable development of thorium-based cycles (Warren and De Simone, 2014). In the gap (2030-2050), thorium may be used to save uranium resources, improve spent fuel management and/or plutonium recyclability (Energy Policy Editorial, 2014). It could become particularly attractive if uranium resource is rarefying whereas fast reactor deploy- ment remains limited for this period.

Medium term thorium options should lie in conservative assumptions with respect to technological breakthroughs and new facilities at industrial scale. Thorium/uranium/plutonium reprocessing is still under development (Patak et al., 2003; Shatalov et al., 2001) and may require hot cells shielded with over $40 \mathrm{~cm}$ of leadglass (Leniau, 2013) since ${ }^{208} \mathrm{Tl}$, a decay product of ${ }^{232} \mathrm{U}$ extracted with ${ }^{233} \mathrm{U}$, is a $2.6 \mathrm{MeV} \gamma$ emitter. Since heterogeneous cores make possible specific reprocessing chains dedicated to thorium spent fuels, thorium fuel may be loaded in-pile with heterogeneity at the level of the fuel assembly (NEA, 2014). The capacity of the thorium fuel reprocessing facility could therefore remain reasonably low. Besides, before 2050, thorium should be introduced in existing reactors such as generation III pressurized water reactors (PWR) initially developed for the U/Pu fuel cycle, with only minor changes brought to expand their fuel acceptance.

Thorium is a fertile element, thus PWR thorium fuel must contain a fissile material, low-enriched uranium (LEU) or plutonium from LEU reprocessing in a first stage. If some LEU is incorporated into a thorium matrix, its enrichment has to remain below 20 wt\% to abide by the international non-proliferation treaties. Practically, its enrichment should be close to $20 \mathrm{wt} \%$ so that the thorium content would remain as high as possible in the $\mathrm{U} / \mathrm{Th}$ fuel. In this case, it should be necessary to feed the cycle with significantly larger amounts of natural uranium (NatU) and separative work units than for the standard

\footnotetext{
* Corresponding author.

E-mail address: guillaume.martin@cea.fr (G. Martin).
} 
uranium cycle for a same energy output (NEA, 2014). At the opposite, $\mathrm{Pu} / \mathrm{Th}$ fuel does not need isotopic enrichment and may be deployed relatively rapidly since it possesses similar neutronic properties than the well-established MOX fuel (Insulander and Fhager, 2009). In this study, thorium is therefore introduced in the core of European pressurized water reactors ( $\mathrm{EPR}^{\mathrm{TM}}$ ) by means of heterogeneous assemblies, each composed of a LEU seed and a Pu/Th fuel ring.

In the 2030-2050 period, $\mathrm{Pu} / \mathrm{Th}$ fuel reprocessing is assumed to occur at the scale of a pilot plant of limited capacity. Thus, although ${ }^{233} \mathrm{U}$-rich uranium might be recycled into LEU to save the most possible natural uranium and enrichment energy (Vallet, 2012), it is used here in the re-fabrication of new $\mathrm{Pu} / \mathrm{Th}$ rings. This way to proceed circumscribes hot cell reprocessing and re-fabrication steps to the single $\mathrm{Pu} / \mathrm{Th}$ fuel. It moreover makes plutonium multi-recycling particularly viable (see part 3.1). The synergy between U/Pu and U/ Th cycles therefore carries substantial results in terms of resource savings concomitantly with better spent fuel and plutonium management essentially. These results are highlighted by comparing scenarios which simulate small fleets of $8 \mathrm{EPR}^{\mathrm{TM}}$ with various fuel loading schemes.

\section{Simulation}

\subsection{Reactors}

The concept of $\mathrm{EPR}^{\mathrm{TM}}$ core with thorium developed by AREVA and LightBridge (AREVA, 2010) is constituted of $17 \times 17$ hybrid assemblies: the seed contains LEU enriched to $4.9 \%$ and the two peripheral raws a (Th,Pu)OX fuel with initially $8 \% \mathrm{Pu}$ (for a plutonium typical of the stock available in France in 2035). Fig. 1 shows a scheme of such an assembly with guide rods visible in the seed part. In the reactor core, the fuel contained into $\mathrm{Pu} / \mathrm{Th}$ rings weights approximately 50 tons (heavy metal): it represents around $45 \%$ of the total fuel mass. This core concept offers a relatively poor conversion ratio of thorium since the EPR ${ }^{\mathrm{TM}}$ operates in a thermal neutron spectrum optimized for the U/ $\mathrm{Pu}$ cycle (Ernoult, 2014). However thorium addition is generally favorable to $\mathrm{Pu}$ incineration. This is the case in light water reactors (LWR) (Weaver and Herring, 2003), so the use of thorium as a vector for Pu multi-recycling actually makes sense (see Section 3.1).

As current French PWR, EPR ${ }^{\mathrm{TM}}$ can also be fueled with 100\% LEU or with MOX fuel (from $30 \%$ to $100 \%$ (Tiphine et al., 2015)). $\mathrm{EPR}^{\mathrm{TM}}$ is in this respect a versatile reactor compatible with advanced fuel cycles (Vezzoni et al., 2009; Martin et al., 2016). LEU is then enriched to $4.2 \%$. MOX refers to a (U,Pu) oxide fuel made with depleted uranium from LEU enrichment and plutonium from used LEU reprocessing (as

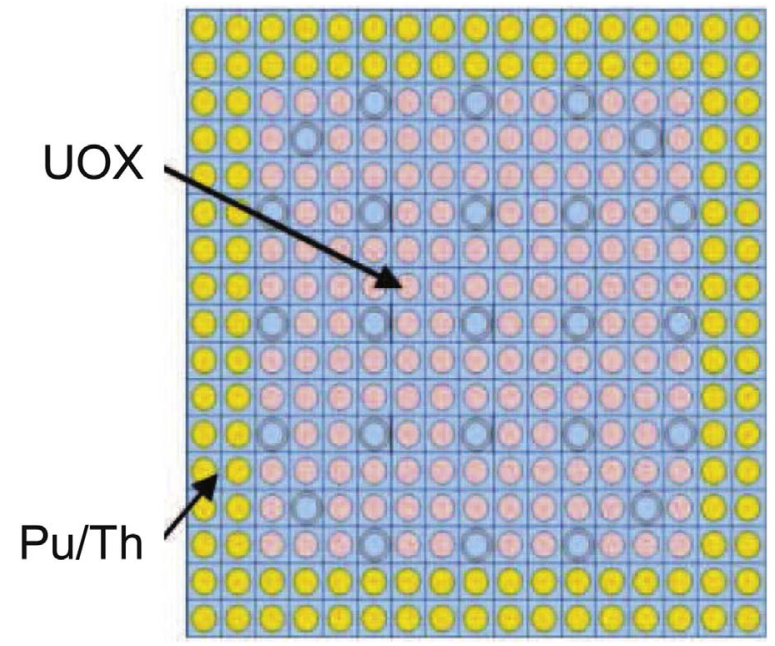

Fig. 1. Scheme of the $17 \times 17$ assembly with a $\mathrm{Pu} / \mathrm{Th}$ ring of 2 raws designed for $\mathrm{EPR}^{\mathrm{TM}}$ (AREVA, 2010). currently done in France). A constant 0.83 load factor is assumed for $\mathrm{EPR}^{\mathrm{TM}}$ and its nominal power is nearly $1.53 \mathrm{GWe}$ regardless of its loading. Fuel core management is carried out by thirds. All the fuels are irradiated during 3 cycles of 517 equivalent full power days, at the end of which $\mathrm{Pu} / \mathrm{Th}$ rods reach a burnup of $61 \mathrm{GWd} / \mathrm{t}$.

\subsection{Fuel cycle}

MOX fuel batches are stored after irradiation since their recycling in PWR would require plutonium contents in new fuels higher than the current safety limits (Martin et al., 2016). In this respect, fast neutron reactors shall be used in France to absorb used MOX fuels first and foremost. $\mathrm{LEU}$ and $\mathrm{Pu} / \mathrm{Th}$ fuel reprocessing are here supposed to occur in distinct facilities. The LEU reprocessing plant is here similar to $\mathrm{La}$ Hague, except that its capacity is lower. The $\mathrm{Pu} / \mathrm{Th}$ reprocessing plant is assumed to separate uranium, plutonium and thorium with $99.9 \%$ efficiency. $\mathrm{Pu} / \mathrm{Th}$ is recycled following these steps:

1. The ${ }^{233} \mathrm{U}$-rich uranium from spent $\mathrm{Pu} / \mathrm{Th}$ rings (RepU) is used to supply the new $\mathrm{Pu} / \mathrm{Th}$ fuel.

2. The plutonium from spent rings is then added in the new rings as a supplementary fissile material.

3. If the new $\mathrm{Pu} / \mathrm{Th}$ fuel still lack fissile atoms, some high-grade plutonium from LEU reprocessing is then withdrawn.

4. The remaining part of the new rings is then completed with fertile thorium. Th coming from $\mathrm{Pu} / \mathrm{Th}$ reprocessing is first consumed.

5. Some natural thorium is eventually provided to complete the $\mathrm{Pu} / \mathrm{Th}$ fuel fabrication.

For sake of clarity, Fig. 2 illustrates the fuel cycle of the scenario $\mathrm{Pu} / \mathrm{Th}-\mathrm{MOX}$ (see part 2.3). It must be highlighted that the feasibility of the scenarios is conditioned by major assumptions, which include the industrialization of the thorium fuel recycling and re-fabrication processes. Thorium fuel fabrication should not constitute a major issue since some $\mathrm{Pu} / \mathrm{Th}$ fuel has already been made (Insulander et al., 2013, 2015) and the building of a pilot manufacturing line was even initiated in Brazil (U/Th fuel) (Fortini et al., 2015). Besides, separate extraction of uranium, plutonium and thorium is now possible at the lab scale (NEA, 2014), but thorium fuels remain particularly hard to dissolve (use of hydrofluoric acid in the nitric solution). At last, thorium fuel refabrication may also constitute a challenge regarding radiation protection.

All the irradiated fuel batches are cooled at least 5 years before their transport and reprocessing. This period is probably not best suited for $\mathrm{Pu} / \mathrm{Th}$ fuels. However, although the cooling time of thorium fuels impacts the kinetics at which the scenarios evolve, it should not affect the results when a steady-state is reached. In the same way, fabrication always lasts 2 years whatever the fuel type and composition, including prior reprocessing if any.

\subsection{Scenarios}

5 scenarios of $8 \mathrm{EPR}^{\mathrm{TM}}$ were simulated, possibly representative of small reactor fleets of $12.2 \mathrm{GWe}$ at the scale of a region or a little country. They deliver the same power ( $90 \mathrm{TWhe} / \mathrm{yr}$ ), which facilitates their direct comparison. The COSI6 simulation code (Coquelet-Pascal et al., 2015) was used. It relies on the CESAR5.3 code and JEFF-3.1.1 nuclear data library (Vidal et al., 2012), and remains a reference in the domain of electronuclear scenarios.

The $8 \mathrm{EPR}^{\mathrm{TM}}$ are fueled with LEU only when they start at $\mathrm{t}_{0}$, since there is no plutonium to make any MOX or $\mathrm{Pu} / \mathrm{Th}$ fuel at this stage. LEU is then irradiated for circa 5 years, and stored for cooling during at least 5 additional years before reprocessing. Accounting for 2 more years of fuel fabrication, 12 years elapse between $t_{0}$ and the introduction of first MOX or $\mathrm{Pu} / \mathrm{Th}$ fuels in-pile. In the same way, the matters from $\mathrm{Pu} / \mathrm{Th}$ reprocessing are recycled into new $\mathrm{Pu} / \mathrm{Th}$ rings after 12 


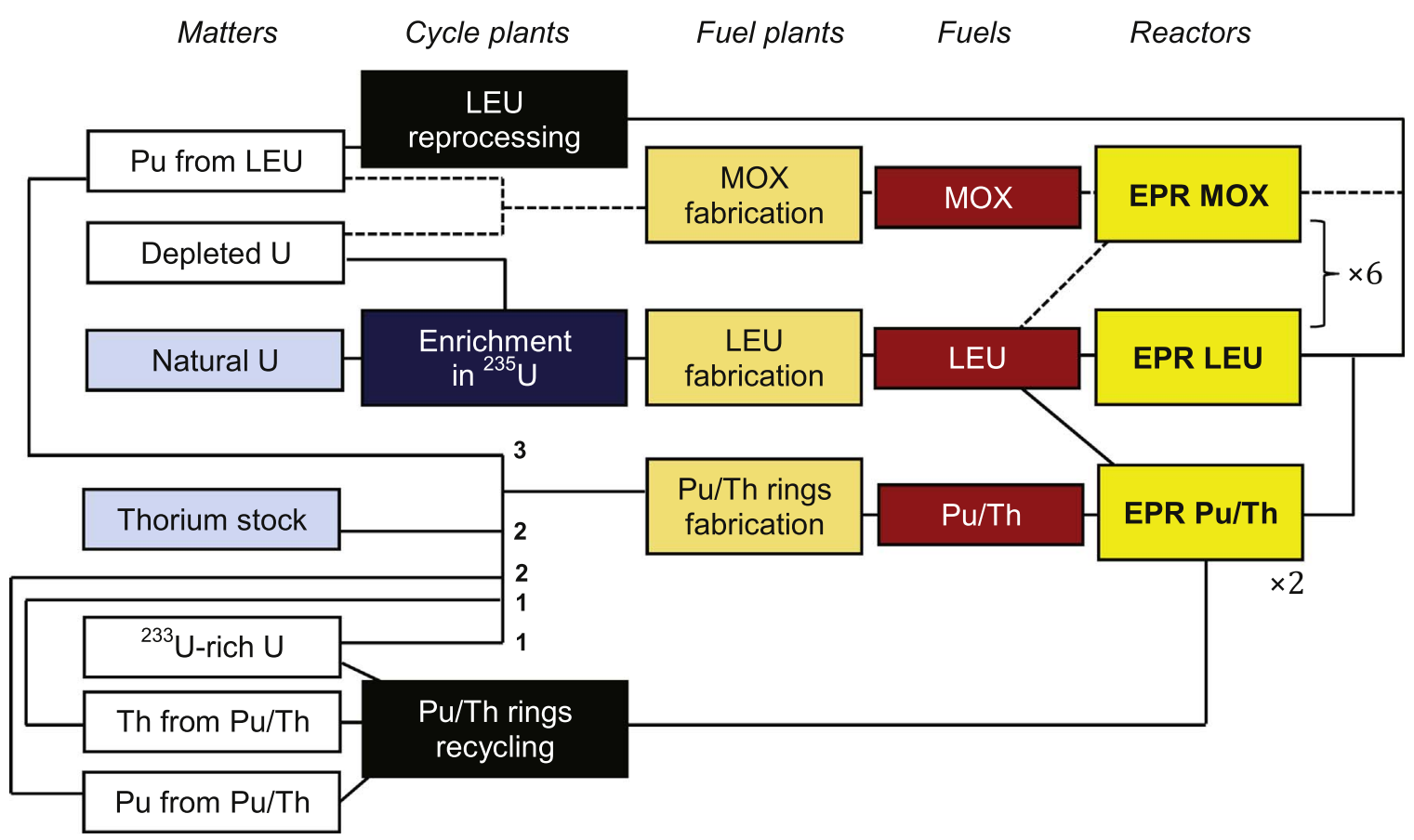

Fig. 2. Scheme of the fuel cycle during the scenario Pu/Th-MOX (see Section 2.3). Small bold numbers indicate the withdrawal order of fissile and fertile elements.

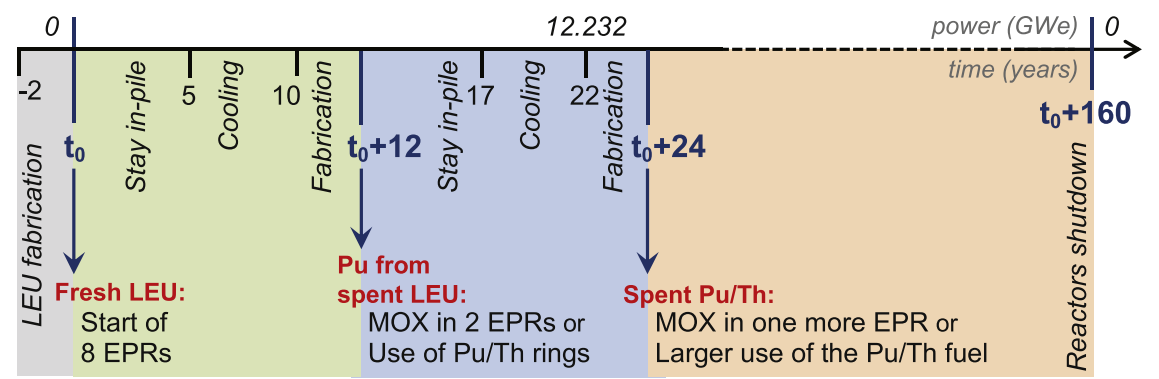

Fig. 3. Chronology of simulated scenarios.

extra years, from year $\left(t_{0}+24\right)$. Simulated fleets follow the timetable exposed in Fig. 3, 12 years being the characteristic timescale at which the fuel streams can change.

The simplest scenario 8xLEU simulates $8 \mathrm{EPR}^{\mathrm{TM}}$ fueled with LEU (one-through cycle). 2xMOX scenario is to some extent representative of the current French cycle. Spent LEU are reprocessed and extracted plutonium is recycled into MOX fuel. It is possible to fuel $2 \mathrm{EPR}^{\mathrm{TM}}$ with $30 \%$ MOX from spent LEU produced by a fleet of $8 \mathrm{EPR}^{\mathrm{TM}}$. To enable a straightforward comparison between $30 \% \mathrm{MOX}$ and $\mathrm{Pu} / \mathrm{Th} \mathrm{EPR}^{\mathrm{TM}}$, a scenario with 2 reactors fueled with $\mathrm{LEU}$ and $\mathrm{Pu} / \mathrm{Th}$ hybrid assemblies was built up (named $2 \mathrm{xPu} / \mathrm{Th}$ ).

${ }^{233} \mathrm{U}$-rich uranium and plutonium from used rings are multirecycled, which leads to fissile material savings. Some plutonium may therefore be used to fabricate MOX fuel, as in the scenario $\mathrm{Pu} / \mathrm{Th}$ MOX. With $2 \mathrm{EPR}^{\mathrm{TM}}$ fueled in $\mathrm{Pu} / \mathrm{Th}$ rings from $\left(\mathrm{t}_{0}+12\right)$, it has indeed been possible to feed $1 \mathrm{EPR}^{\mathrm{TM}}$ in $30 \% \mathrm{MOX}$ from $\left(\mathrm{t}_{0}+24\right)$. Another way to benefit from the saved fissile material is to fabricate more $\mathrm{Pu} / \mathrm{Th}$ fuel. During the scenario $\mathrm{Pu} / \mathrm{Th}-\mathrm{Max}, 2 \mathrm{EPR}^{\mathrm{TM}}$ are fueled with $\mathrm{Pu} / \mathrm{Th}$ 12 years after reactors start. 12 years later, one more reactor was fed in $\mathrm{Pu} / \mathrm{Th}$ fuel. Then it was possible to fuel 2 more reactors with $\mathrm{Pu} / \mathrm{Th}$ rings from $\left(t_{0}+36\right)$ and $\left(t_{0}+62\right)$. The composition of the 5 simulated fleets at equilibrium is summarized in Table 1 .
Table 1

Equilibrium composition of simulated reactor fleets. Bold numbers refer to reactors which number was maximized to the detriment of LEU EPR ${ }^{\mathrm{TM}}$.

\begin{tabular}{ccccc}
\hline & \multicolumn{3}{c}{ Fleet composition } & $\begin{array}{c}\text { Pu/Th fuel } \\
\text { fabrication }\end{array}$ \\
\cline { 2 - 4 } $\begin{array}{c}\text { Scenario } \\
\text { name }\end{array}$ & LEU EPR $^{\mathrm{TM}}$ & $\begin{array}{c}30 \% \mathrm{MOX} \\
\mathrm{EPR}^{\mathrm{TM}}\end{array}$ & $\begin{array}{c}\mathrm{Pu} / \mathrm{Th} \\
\mathrm{EPR}^{\mathrm{TM}}\end{array}$ & and recycling \\
\hline 8xLEU & 8 & & & \\
$2 \mathrm{xMOX}$ & 6 & $\mathbf{2}$ & & yes \\
2xPu/Th & 6 & & 2 & yes \\
$\mathrm{Pu} / \mathrm{Th}-\mathrm{MOX}$ & 5 & $\mathbf{1}$ & 2 & yes \\
$\mathrm{Pu} / \mathrm{Th}-\mathrm{Max}$ & 3 & & $\mathbf{5}$ & \\
\hline
\end{tabular}

\section{Results}

\section{1. $\mathrm{Pu} /$ Th fuel multi-recycling}

Since the key results of this study lie on the possibility to multirecycle the $\mathrm{Pu} / \mathrm{Th}$ rings introduced in $\mathrm{PWR}$, its viability has been examined. As presented in part 2.2, the fissile material which is first withdrawn to be recycled into new $\mathrm{Pu} / \mathrm{Th}$ fuel is the ${ }^{233} \mathrm{U}$-rich uranium, which stems from the ${ }^{232} \mathrm{Th}$ converted by neutron capture under in-pile irradiation. Fig. 4 shows the grade and content of RepU introduced into fresh $\mathrm{Pu} / \mathrm{Th}$ rings during the scenarios $2 \mathrm{xPu} / \mathrm{Th}$ and $\mathrm{Pu} / \mathrm{Th}-\mathrm{Max}$. The 


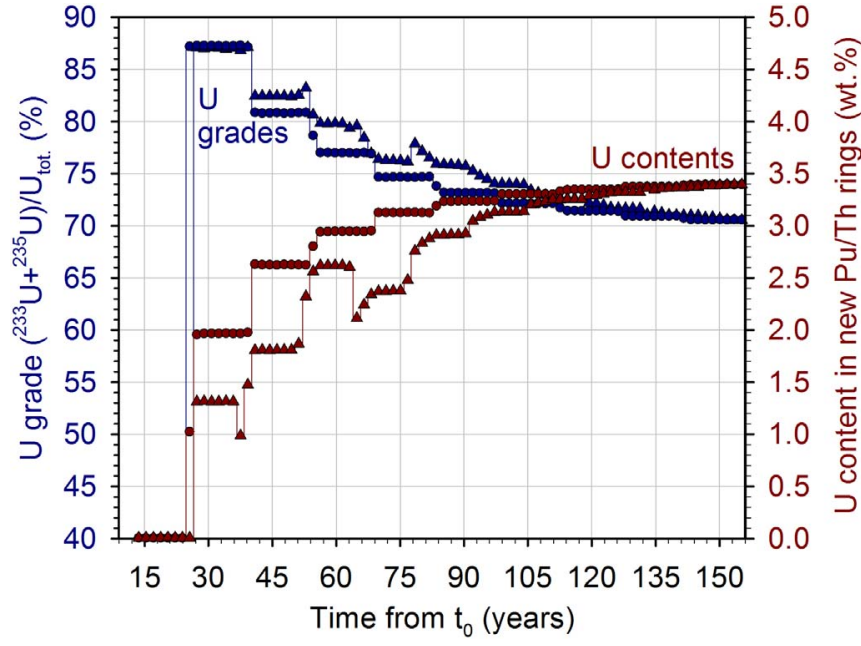

Fig. 4. Uranium grade (left scale) and content (right scale) in fresh $\mathrm{Pu} / \mathrm{Th}$ rings during the scenarios $2 \mathrm{xPu} / \mathrm{Th}$ (circles) and $\mathrm{Pu} / \mathrm{Th}-\mathrm{Max}$ (triangles).

uranium grade, here defined as the weight ratio of its fissile isotopes, is very high in the first recycled rings, near $90 \%$. It then progressively degrades with the number of cycles since the non consumed fraction, relatively rich in non fissile isotopes, accumulates within the $\mathrm{Pu} / \mathrm{Th}$ fuel. From another angle, this degradation is partly countered by the continuous production of high-grade uranium through thorium conversion. The uranium grade therefore converges to a high value above $70 \%$. In addition, it is worth noting that the content in ${ }^{232} \mathrm{U}$, which mainly derives from ${ }^{233} \mathrm{U}$ and results in high-energy $\gamma$ emitters, tends to slightly decrease over time and always remains below $0.5 \%$.

The uranium accumulation in $\mathrm{Pu} / \mathrm{Th}$ fuel also leads to increasing uranium contents in fresh rings, which converge to a value near $3.5 \mathrm{wt}$ $\%$. ${ }^{233} \mathrm{U}$-rich RepU is a relatively stable matter, since uranium fissile isotopes possess longer half-lives than plutonium ones. This high-grade uranium from $\mathrm{Pu} / \mathrm{Th}$ reprocessing may constitute a proliferating material and might require a $\mathrm{U} / \mathrm{Pu}$ co-management, a priori compatible with the THOREX process (NEA, 2014).

Multi-recycling also implies a plutonium accumulation leading to its degradation, as shown in Fig. 5. Since the plutonium contained in $\mathrm{Pu} / \mathrm{Th}$ rings is not enough to feed the reactors, it is at any time entirely consumed (as is the high-grade uranium, which makes $\mathrm{U} / \mathrm{Pu}$ coextraction relevant here). It must be completed with high-grade plutonium from LEU reprocessing (at least $57 \%$ of the total Pu within new rings). The plutonium grade therefore levels off around $40 \%$

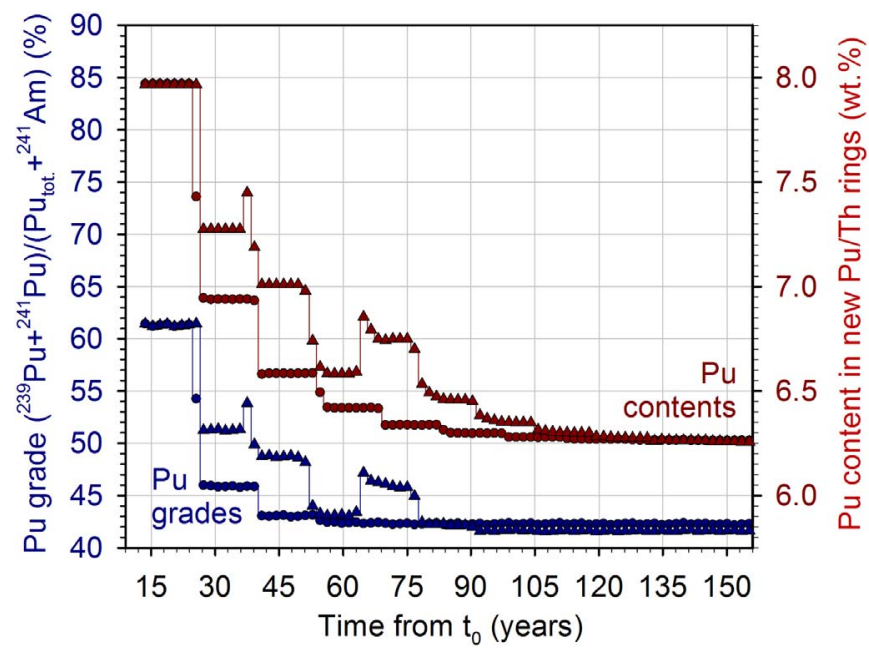

Fig. 5. Plutonium grade (left scale) and content (right scale) in fresh $\mathrm{Pu} / \mathrm{Th}$ rings during the scenarios 2xPu/Th (circles) and $\mathrm{Pu} / \mathrm{Th}-\mathrm{Max}$ (triangles).

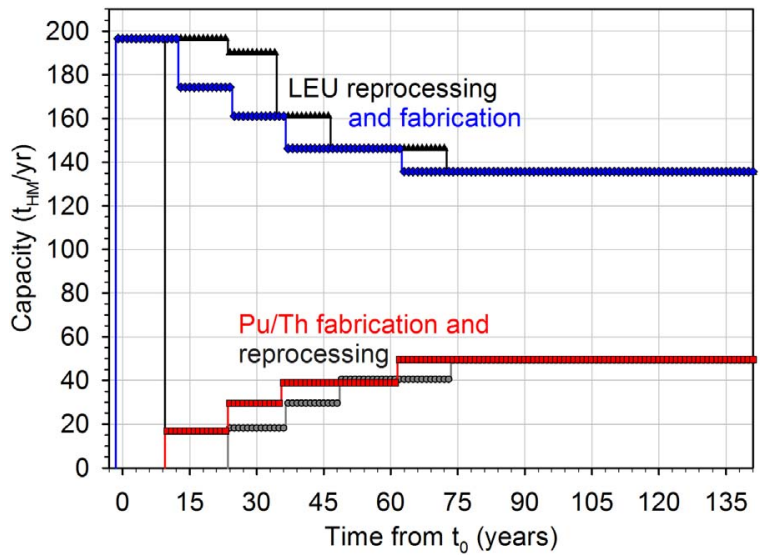

Fig. 6. Fabrication and reprocessing capacities during the scenario $\mathrm{Pu} / \mathrm{Th}-\mathrm{Max}$.

thanks to this uninterrupted plutonium supply of high grade over $60 \%$, here defined including ${ }^{241} \mathrm{Am}$ (Martin et al., 2016).

In multi-recycled MOX fuel, plutonium degradation induces increasing Pu contents up to unacceptable levels. Here, Pu content drops from $8.0 \%$ to $6.3 \%$ although its grade falls by $20 \%$. This decrease stems from the rising $\mathrm{RepU}$ input that the applied $\mathrm{Pu} / \mathrm{Th}$ recycling strategy implies. This result indicates that the multi-recycling of $\mathrm{Pu} / \mathrm{Th}$ fuel in PWR may be particularly viable especially with respect to MOX fuel. Furthermore, the multi-recycling of fuel rings circumscribes $\mathrm{Pu} / \mathrm{Th}$ reprocessing and re-fabrication to low capacities, as shown in Fig. 6. During the scenario $\mathrm{Pu} / \mathrm{Th}-\mathrm{Max}$ with $5 \mathrm{EPR}^{\mathrm{TM}}$ fueled in thorium, $\mathrm{Pu}$ / Th cycle plants operate near $50 \mathrm{t} / \mathrm{yr}\left(\approx 10 \mathrm{t} / \mathrm{yr} / \mathrm{EPR}^{\mathrm{TM}}\right)$, providing fuel batches can be disassembled to separate $\mathrm{Pu} / \mathrm{Th}$ and LEU rods.

\subsection{Thorium}

Thorium is multi-recycled in $\mathrm{Pu} / \mathrm{Th}$ rings here. Once scenarios reach a steady-state, its consumption therefore corresponds to the thorium stream which is converted in-pile (essentially into ${ }^{233} \mathrm{U}$ ). Fig. 7 reveals that the thorium conversion is rather constant near $3.85 \%$ (the reactor conversion factor being near 0.5). Thorium consumption at equilibrium remains near $0.35 \mathrm{t} / \mathrm{yr} / \mathrm{EPR}^{\mathrm{TM}}$. Without thorium recycling, the consumption would be $9.1 \mathrm{t} / \mathrm{yr} / \mathrm{EPR}^{\mathrm{TM}}$, which nevertheless remains low with respect to the French stock of available thorium of $8500 t_{\mathrm{HM}}$ resulting from mining activities (ANDRA, 2012).

Thorium is a mononuclidic element: only the ${ }^{232} \mathrm{Th}$ isotope exists naturally. Only few ppm of isotopic impurities are produced during $\mathrm{Pu} /$

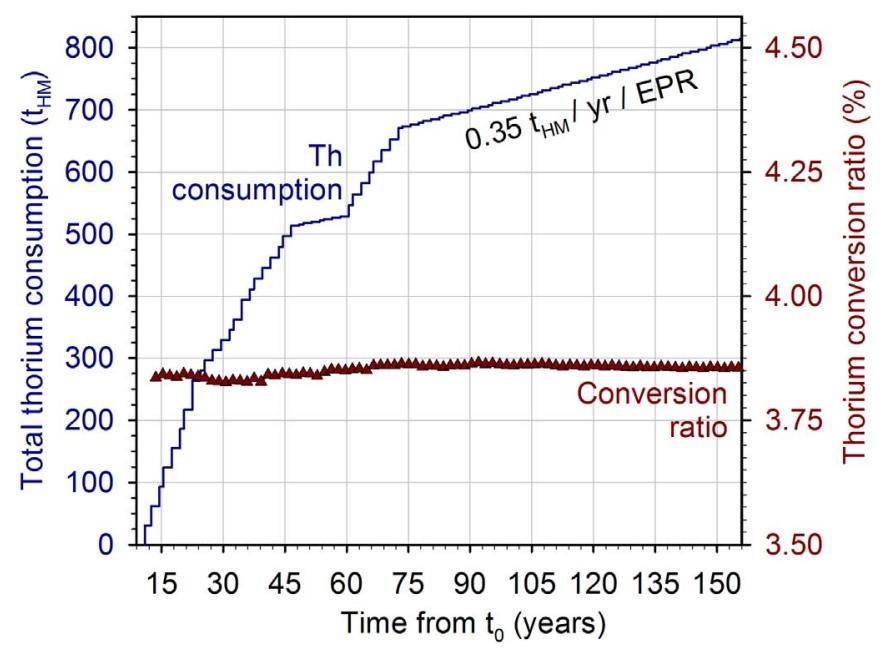

Fig. 7. Thorium consumption (left scale) and conversion (right scale) in the scenario $\mathrm{Pu} /$ Th-Max. 


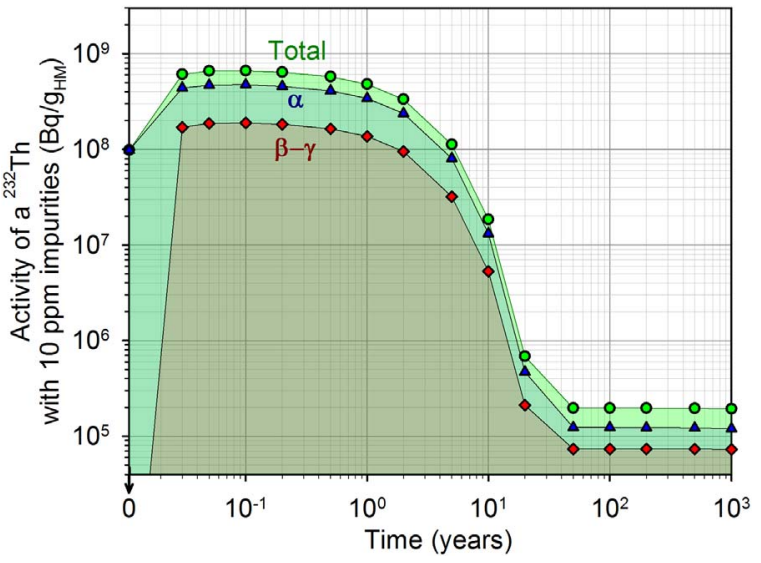

Fig. 8. Activity of thorium in a $\mathrm{Pu} / \mathrm{Th}$ fuel irradiated at $61 \mathrm{GWd} / \mathrm{t}$, with a content of $10 \mathrm{ppm}$ of isotopic impurities, calculated with CESAR5.3.

Th fuel irradiation. The content in thorium isotopic impurities levels off around $10 \mathrm{ppm}$ since these impurities are consumed in-pile and/or decay fast, with half-lives ranging from several milliseconds to few tens of thousand years. But they considerably increase the thorium activity. Whereas natural thorium activity is near $40 \mathrm{kBq} / \mathrm{g}$ including the activity of daughter products, an irradiated thorium with $10 \mathrm{ppm}$ impurities would have an activity over $100,000 \mathrm{kBq} / \mathrm{g}$. This activity is essentially $\alpha$ but rises fast, as shown in Fig. 8, since decay products are radioactive elements, some of them as ${ }^{208} \mathrm{Tl}$ being high-energy $\gamma$ emitters. It is eventually akin to the activity of ${ }^{233} \mathrm{U}$-rich RepU which concentrates ${ }^{232} \mathrm{U}$. Therefore radiation protection means (namely hot cells) adapted to RepU extraction and recycling within $\mathrm{Pu} / \mathrm{Th}$ reprocessing and re-fabrication plants may also possibly work for reprocessed thorium management.

This activity nevertheless falls after few decades of cooling. In that context, a deferred thorium reprocessing after cooling periods exceeding 20 years has been envisaged (NEA, 2014). Another way would consist in a very fast on-line fuel reprocessing before the $\gamma$ activity rises, as imagined in molten-salt reactors with a liquid fuel primary circuit. This last solution does not apply to PWR since timescales are too short for solid fuel unloading, transport, reprocessing and in reactor loading operations.

\subsection{Natural uranium}

In LWR, thorium usually aims at saving natural uranium primarily. In such reactors, natural uranium consumption is directly related to LEU needs and enrichment. ${ }^{233} \mathrm{U}$ partial substitution for ${ }^{235} \mathrm{U}$ in LEU fuel can efficiently reduce uranium resource consumption: 30-40\% savings may be attained according to NEA (2014) in comparison to a one-through cycle. In this study however, ${ }^{233} \mathrm{U}$ is recycled into new $\mathrm{Pu} /$ Th fuel. The main objective is therefore to benefit from plutonium multi-recycling.

Natural uranium savings are nonetheless a sign of an efficient use of fissile elements and remain of importance. They directly depend here on the LEU fraction inside reactor cores. The uranium consumption logically falls as the fraction of MOX fuel and $\mathrm{Pu} / \mathrm{Th}$ rings rises in the fleet. This is visible in Table 2. While around $10 \%$ of the fuel is MOX fuel in the small EPR ${ }^{\mathrm{TM}}$ fleet (scenario 2xMOX with Pu recycled once), improved plutonium management in $\mathrm{Pu} / \mathrm{Th}$ rings rises the fraction of non LEU fuel loaded in-pile to more than $25 \%$. Savings over $25 \%$ may therefore be reached at the equilibrium of the $\mathrm{Pu} / \mathrm{Th}-\mathrm{Max}$ scenario when compared to a one-through cycle (scenario 8xLEU).

\subsection{Spent fuel}

Table 3 shows the balance of spent fuel streams for each scenario.
Table 2

Natural uranium needs at the equilibrium of the scenarios.

\begin{tabular}{ccccc}
\hline \multirow{2}{*}{ Scenario } & & \multicolumn{3}{c}{ Resources consumption } \\
& & & & \\
\cline { 3 - 5 } name & LEU fraction at & NatU (t/yr) & Enrich. (kSWU/ & Dep. U (t/yr) \\
& eq. (wt\%) & & yr) & \\
\hline 8xLEU & 100 & -1727 & 1259 & 1525 \\
2xMOX & 92.5 & -1597 & 1165 & 1397 \\
2xPu/Th & 89.9 & -1536 & 1129 & 1361 \\
$\mathrm{Pu} / \mathrm{Th}-\mathrm{MOX}$ & 86.0 & -1471 & 1081 & 1297 \\
$\mathrm{Pu} / \mathrm{Th}-\mathrm{Max}$ & 73.2 & -1250 & 933 & 1114 \\
\hline
\end{tabular}

Table 3

Reprocessing capacity and spent fuel accumulation at the equilibrium of the scenarios.

\begin{tabular}{|c|c|c|c|c|c|c|}
\hline \multirow{3}{*}{$\begin{array}{c}\text { Scenario } \\
\text { name }\end{array}$} & \multicolumn{6}{|c|}{ Balance at equilibrium (t/yr) } \\
\hline & \multicolumn{2}{|c|}{ Rep. capacity } & \multicolumn{4}{|c|}{ Spent fuel accumulation } \\
\hline & LEU & $\mathrm{Pu} / \mathrm{Th}$ & LEU & MOX & $\mathrm{Pu} / \mathrm{Th}$ & Total \\
\hline 8xLEU & & & 196 & & & 196 \\
\hline $2 x M O X$ & 130 & & 60 & 16 & & 76 \\
\hline $2 \mathrm{xPu} / \mathrm{Th}$ & 60 & 20 & 111 & & 0 & 111 \\
\hline $\mathrm{Pu} / \mathrm{Th}-\mathrm{MOX}$ & 120 & 20 & 43 & 8 & 0 & 51 \\
\hline $\mathrm{Pu} / \mathrm{Th}-\mathrm{Max}$ & 135 & 49 & 0 & & 0 & 0 \\
\hline
\end{tabular}

This balance is related to the reprocessing capacity, which is adjusted to provide enough plutonium to make the MOX and $\mathrm{Pu} / \mathrm{Th}$ fuels. Since the stream of irradiated fuel unloaded from reactor cores is basically the same in all the scenarios, the difference in spent fuel accumulation stems from the quantity of fuel going to reprocessing and recycled into new fuel. The improved management of fissile elements contained in used fuels during the scenarios $\mathrm{Pu} / \mathrm{Th}-\mathrm{MOX}$ and $\mathrm{Pu} / \mathrm{Th}-\mathrm{Max}$ requires relatively high reprocessing capacities: it then results in a lower spent fuel accumulation at equilibrium. In the case of the scenario $\mathrm{Pu} / \mathrm{Th}-$ Max, all the irradiated fuels are reprocessed and spent fuel accumulation is therefore nullified.

\subsection{Plutonium}

The plutonium accumulation results from a balance between its production, essentially through ${ }^{238} \mathrm{U}$ neutron captures, and its consumption in MOX and/or Pu/Th fuels. Plutonium inventories at the fuel cycle back-end of all the scenarios are reported in Fig. 9. Inventories at the cycle back-end are here defined as quantities of an element in the stocks of separated matters (from reprocessing) and inside spent fuels. Using MOX fuel reduces by a quarter the production of plutonium at the cycle back-end compared to a one through cycle. With thorium and a better plutonium management, the $\mathrm{Pu}$ accumulation falls. Reduction exceeds 50\% in the scenario $\mathrm{Pu} / \mathrm{Th}-\mathrm{MOX}$. The $\mathrm{Pu}$ eventually levels off in the scenario $\mathrm{Pu} / \mathrm{Th}-\mathrm{Max}$, with an inventory remaining below 50 tons. This result is due to the fact that $\mathrm{Pu}$ multirecycling makes possible its complete incineration.

According to the last NEA report on thorium (NEA, 2014), since commercial fast reactors should need several tons of plutonium to start, a reduction of $\mathrm{Pu}$ quantity at the cycle back-end may penalize their deployment in countries which would like to transition to this technology. In this respect, the fraction of MOX fuel and a fortiori $\mathrm{Pu} /$ Th fuel in the reactor fleet may therefore be adjusted to limit $\mathrm{Pu}$ consumption in the perspective of starting fast reactors. The versatile $\mathrm{EPR}^{\mathrm{TM}}$ core concept proposed here should facilitate rapid changes in fuel loading (LEU, MOX or $\mathrm{Pu} / \mathrm{Th}$ rings), so that the plutonium 


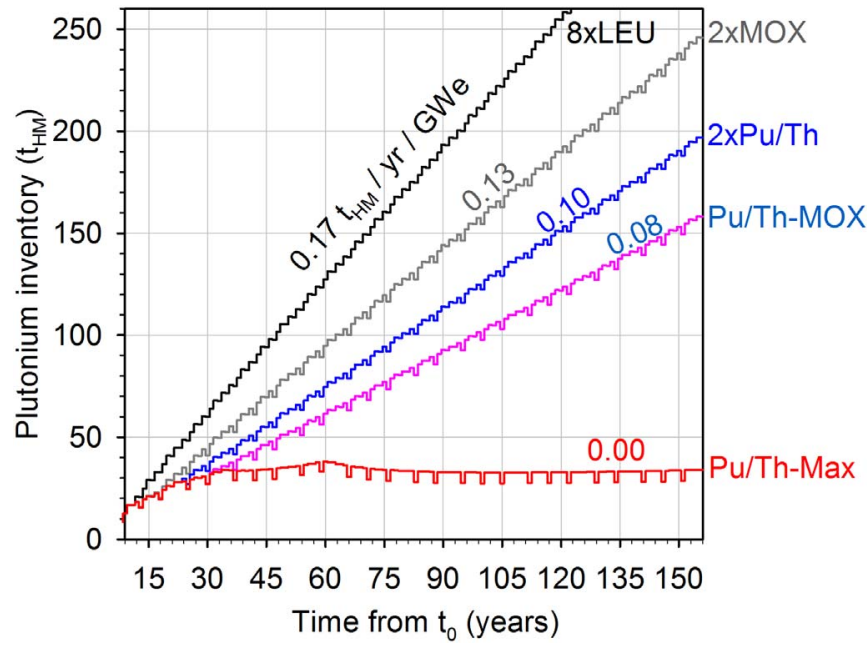

Fig. 9. Plutonium inventory at the cycle back-end.

inventory could be piloted according to governmental energy policies. In that context, there should be no risk of compromising the deployment of fast reactors using thorium in $\mathrm{EPR}^{\mathrm{TM}}$.

\subsection{Minor actinides}

In current PWR, minor actinides (MA), namely americium, neptunium and curium, are produced in-pile by neutron captures of uranium and plutonium atoms and subsequent nuclear reactions. Thorium is relatively light: its transmutation into minor actinides require multiple neutron captures so that it generally leads to lower MA production for a same irradiation sequence. Thus MA accumulation remains lower for scenarios with $\mathrm{Pu} / \mathrm{Th}$ fuel multi-recycling in comparison to the LEU reference scenario, as visible in Table 4 which gathers equilibrium MA productions at the cycle back-end.

However, thorium fuel implies here plutonium multi-recycling and multiple irradiation sequences very favorable to curium production: for the scenario $\mathrm{Pu}-\mathrm{Th} / \mathrm{Max}$, it is around one order of magnitude greater than for the scenarios 8xLEU and 2xMOX, representative of existing $\mathrm{U} / \mathrm{Pu}$ fuel cycles. Short-lived isotopes of curium are particularly penalizing in terms of radiation protection and their presence in large quantities could complicate $\mathrm{Pu} / \mathrm{Th}$ reprocessing and waste package conditioning steps.

Finally, the thorium cycle produces another minor actinide: protactinium. ${ }^{233} \mathrm{~Pa}$ is formed during the thorium conversion. Its period is 27 days so it is essentially present in reactor cores. Its neutron capture section in thermal spectrum is quite high, 110 barns, which can be detrimental to high flux (Greneche et al., 2008). Outside reactors, the residual amount of Pa consists mainly in ${ }^{231} \mathrm{~Pa}$ of period 32,760 years which $\alpha$ activity (312 keV) can be embarrassing. Fig. 10 shows the protactinium during the scenario $2 \mathrm{xPu} / \mathrm{Th}$ (with $2 \mathrm{EPR}^{\mathrm{TM}}$ fueled with

Table 4

Minor actinides accumulation at the cycle back-end once equilibrium of the scenario is reached.

Scenario LEU fraction at eq. (wt\%) MA production $(\mathbf{k g} / \mathbf{y r})$

\begin{tabular}{cccccc}
\cline { 3 - 5 } Name & & Am & Np & Cm & Total \\
\hline 8xLEU & 100 & 366 & 191 & 2 & 559 \\
2xMOX & 92.5 & 397 & 182 & 5 & 584 \\
2 xPu/Th & 89.9 & 352 & 173 & 12 & 537 \\
Pu/Th-MOX & 86.0 & 367 & 168 & 14 & 549 \\
Pu/Th-Max & 73.2 & 327 & 147 & 36 & 510 \\
\hline
\end{tabular}

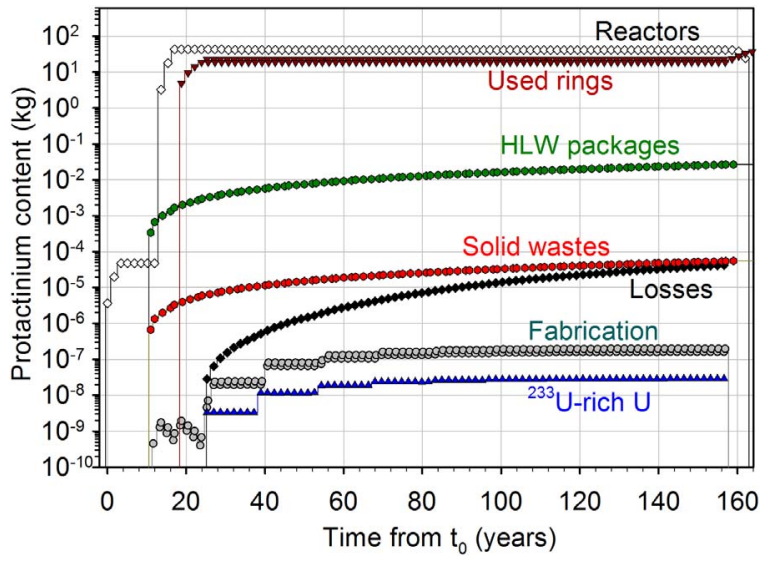

Fig. 10. Protactinium contents (isotope $231-234 \mathrm{~m}$ ) in various places during the scenario $2 \mathrm{xPu} / \mathrm{Th}$.

thorium).

\section{Conclusion and policy implications}

Thorium use could start in PWR in order to develop progressively thorium fuel reprocessing and re-fabrication technologies, while using common reactor concepts originally designed for the $\mathrm{U} / \mathrm{Pu}$ fuel cycle. Heterogeneous core concepts make possible a dedicated recycling of spent thorium fuel into new thorium fuel, and seems therefore the best way to limit the capacity of pioneer thorium facilities.

In PWR, thorium fuel has to contain fissile atoms for efficient breeding. Non-proliferation concerns currently limit uranium enrichment to $20 \%$ in U/Th fuels, which leads to include large amounts of U238 instead of thorium. $\mathrm{Pu} / \mathrm{Th}$ fuel should contain more thorium, but it produces ${ }^{233} \mathrm{U}$-rich reprocessed uranium of high grade which may be considered as a proliferating material. $\mathrm{U} / \mathrm{Pu}$ co-management may tackle this issue however.

In this study, an original $\mathrm{EPR}^{\mathrm{TM}}$ core concept composed of heterogeneous $17 \times 17$ assemblies was implemented. The multi-recycling strategy of $\mathrm{Pu} / \mathrm{Th}$ rings consisted here in using in priority fissile elements from $\mathrm{Pu} / \mathrm{Th}$ fuel reprocessing into the new rings. Plutonium multi-recycling inside rings appeared viable, since its fissile quality stabilized over $40 \%$ with a Pu content remaining under $8 \%$, far below PWR safety limits. This was carried out thanks to the increasing supply of high-grade reprocessed uranium produced in $\mathrm{Pu} / \mathrm{Th}$ rings through thorium conversion (of circa $3.8 \%$ ).

Plutonium multi-recycling offers several outstanding possibilities amongst which substantial savings on natural uranium consumption (over 25\% compared to a one-through cycle), greater than what can be reached through a classical MOX utilization as performed in the current French fleet. Improved Pu management can moreover stabilize spent fuel stocks. At equilibrium, all spent fuel is indeed possibly reprocessed and all the plutonium into it recycled into new $\mathrm{Pu} / \mathrm{Th}$ fuel. Plutonium multi-recycling can lead to the balancing of the plutonium inventory at the cycle back-end, which therefore levels off. In that case thorium use eventually implies a reduction in minor actinides production around $10 \%$, although multiple $\mathrm{Pu}$ irradiation cycles enhance curium production.

Since thorium introduction in standard PWR could lead to substantial resource savings as complete plutonium incineration and spent fuel utilization, it may constitute a sustainable transition for nuclear power development. Thorium is a more abundant resource than uranium worldwide. Therefore countries which target a massive development of their nuclear power in the next decades, as China, might wish to relieve some of the tension in the uranium market by introducing thorium into their existing PWR fleet.

The advanced $\mathrm{Pu} / \mathrm{Th}$ cycle presented here implies that $\mathrm{U} / \mathrm{Pu} / \mathrm{Th}$ 
fuel reprocessing and re-fabrication would become available. However thorium irradiation goes hand in hand with radiation protection concerns since it leads to the production of high-energy $\gamma$ emitters which should require hot cells. In this context substantial amounts of time and money are no doubt necessary to develop appropriate reprocessing and re-fabrication facilities at industrial scale. Such investments may not occur as long as uranium resources remain affordable. Thorium could nevertheless become particularly attractive if uranium resource is rarefying while the fuel cycle is still getting closed, by means of GEN-IV reactors as in France for instance. Such a situation may be encountered in the medium term (in the 2030-2050 period according to NEA).

\section{Acknowledgements}

The authors are grateful to AREVA for its support to this work through the ACF research program. Many thanks to Romain Eschbach, Christine Chabert and Christine Coquelet-Pascal to have inspired the main guidelines of this study, to Gérald Senentz for his careful reading and to Laurent Buiron for fruitful discussions. Guillaume Ritter, Marion Tiphine and Guillaume Krivtchik are also thanked for their help in implementing the codes developed in CEA/DER/SPRC (COSI6 and CESAR5.3).

\section{References}

ANDRA, 2012. Inventaire national des matières et déchets radioactifs, rapport de synthèse 2012, ANDRA report.

AREVA, Lightbridge, 2010. AREVA - Lightbridge consultancy agreement: main results. AREVA - Lightbridge report.

Bomboni, E., Cerullo, N., Lomonaco, G., Romanello, V., 2008. A critical review of the recent improvements in minimizing nuclear waste by innovative gas-cooled reactors. Sci. Technol. Nucl. Install., 265430.

Cerullo, N., Bufalino, D., Forasassi, Lomonaco, G., Rocchi, P., Romanello, V., 2015. An additional performance of HTRs: the waste radiotoxicity minimisation. Radiat. Prot. Dosim. 115, 122-125.

Cerullo, N., Lomonaco, G., 2012. Generation IV reactor designs, operation and fuel cycle. Chapter in Nuclear Fuel Science and Engineering, Woodhead Publishing Series in Energy, pp. 333-395.

Coquelet-Pascal, C., Tiphine, M., Krivtchik, G., Freynet, D., Cany, C., Eschbach, R., Chabert, C., 2015. COSI6: a tool for nuclear transition scenarios studies and application to SFR deployment scenarios with minor actinides transmutation. Nucl. Technol. 192, 91-110.

Energy Policy Editorial, 2014. Nuclear energy and sustainable development, Energy Policy 74, pp. S1-S4.

Ernoult, M., 2014. Gestion avancée du plutonium en REP - complémentarité des cycles thorium et uranium, Ph.D., Université Paris-Sud.

Fortini, A., Monteiro, F.B.A., Scari, M.E., da Silva, F.C., Sousa, R.V., da Silva, C.A.M. Costa, A.L., Pereira, C., Veloso, M.A.F., 2015. Recent advances on the use of reprocessed fuels and combined thorium fuel cycles in HTR systems. Prog. Nucl. Energy 83, 482-496.

Greneche, D., David, S., Bichaud, A., 2008. Faut-il repenser au thorium ? Article de convention SFEN.

Heuer, D., Merle-Lucotte, E., Allibert, M., Brovchenko, M., Ghetta, V., Rubiolo, P., 2014 Towards the thorium fuel cycle with molten salt fast reactors. Ann. Nucl. Energy 64, 421-429.

Insulander, K., Dreera, S.S., Kelly, J.F., Vitanza, C., Helsengreen, C., Tverberg, T., Sobieska, M., Oberlander, B.C., Tuomitso, H., kekkonen, L., Wright, J., Bergmann, U., Mathers, P., 2015. Commercial thorium fuel manufacture and irradiation: testing (Th, $\mathrm{Pu})_{2}$ and (Th, $\mathrm{U}_{2} \mathrm{O}_{2}$ in the seven-thirty program. Ann. Nucl. Energy 75, 79-86.

Insulander, K., Fhager, V., 2009. Comparison of thorium-plutonium fuel and MOX fuel for PWRs, In: Proceedings of GLOBAL, Paper 9449.

Insulander, K., Mittag, S., Nabbi, R., Rineiski, A., Schitthelm, O., Vezzoni, B., 2013. Irradiation of a thorium-plutonium rodlet: experiment and benchmark. Prog. Nucl. Energy 66, 73-79.

Léniau, B., 2013. Caractérisation des sources radioactives du cycle du combustible application au cycle du thorium, Ph.D., Université Paris-Sud, France.

Martin, G., Tiphine, M., Coquelet-Pascal, C., 2016. French transition scenarios toward a symbiotic nuclear fleet, In: Proceedings of ICAPP, Paper 15732.

Mazzini, G., Bomboni, E., Cerullo, N., Fridman, E., Lomonaco, G., Shwageraus, E., 2008 The use of Th in HTR: state of the art and implementation in Th/Pu fuel cycles. Sci. Technol. Nucl. Install., 749736.

NEA, 2015. Introduction of thorium in the nuclear fuel cycle, NEA Report No. 7224

Patak, P.N., Prabhu, D.R., Manchanda, V.K., 2003. The role of oxidants in Pu-Th separation studies employing di-2-ethylexyl isobutyramide (D2EHIBA) as extractant. Radiochim. Acta 91, 141-146.

Rodriguez, P., Bhoje, S.B., 1998. The FBR program in india. Energy 23, 629-636.

Schaffer, M.B., 2013. Abundant thorium as an alternative nuclear fuel-important waste disposal and weapon proliferation advantages. Energy Policy 60, 4-12.

Shatalov, V.V., Seregin, M.B., Kharin, V.F., Ponomarev, L.A., 2001. Gas-fluoride technology for processing spent oxide fuel. At. Energy 90, 224-234.

Tiphine, M., Coquelet-Pascal, C., Krivtchik, G., Eschbach, R., Chabert, C., Carlier, B., Caron-Charles, M., Senentz, G., Durpel, L.V.D., Garzenne, C., Laugier, F., 2015. Simulations of progressive potential scenarios of Pu multirecycling in SFR and associated phase-out in the French nuclear power fleet, in: Proceedings of Global, Paper 5326.

Vallet, V., 2012. Recherche de l'économie des ressources naturelles par des études de conception de coeurs de réacteurs Ã eau légère et à haut facteur de conversion à combustibles mixtes thorium/uranium/plutonium, Ph.D., Université de Grenoble, France.

Vezzoni, B., Cerullo, N., Forasassi, G., Fridman, E., Lomonaco, G., Romanello, V., Shwageraus, E., 2009. Preliminary evaluation of a nuclear scenario involving innovative gas cooled reactors. Sci. Technol. Nucl. Install., 940286.

Vidal, J.M., Eschbach, R., Launay, A., Binet, C., Thro, J.F., 2012. CESAR5.3: an industrial tool for nuclear fuel and waste characterization with associated qualification, in: Proceedings of the WM2012 Conference, Phoenix, USA.

Warren, P., De Simone, G., 2014. Fuelling the future? Energy Policy 74, S5-S15.

Weaver, K.D., Herring, J.S., 2003. Performance of thorium-based mixed-oxide fuels for the consumption of plutonium in current and advanced reactors. Nucl. Tech. 43, $22-36$. 